\title{
Primers Designed For Amplifying TCF7L2 Gene
}

\author{
Hengki Saputra ${ }^{1}$, Dwi Hilda Putri ${ }^{2}$, Elsa Badriyya ${ }^{3}$, Syamsurizal ${ }^{4 *}$ \\ 124 \\ Department of Biology, FMIPA, Universitas Negeri Padang, Padang, West Sumatra, Indonesia \\ ${ }^{3}$ Faculty of Pharmacy, Universitas Andalas, Padang, West Sumatra, Indonesia \\ *email : syam_unp@fmipa.unp.ac.id
}

Article Info

Key word:

Diabetes Mellitus

TCF7L2 gene,

Designed Primers

Article history:

Received: $30 / 05 / 2020$

Revised: 04/08/2020

Accepted:12/08/2020

\begin{abstract}
Diabetes Mellitus (DM) is a disease characterized by high glucose levels because of the lack of insulin hormone in the body. Prevalence of Type-2 Diabetes Mellitus is associated with the variant of the TCF7L2 gene polymorphism, or SNP. The purpose of this study was to construct a specific primer to amplify the TCF7L2 gene fragment and their capabilities to detect the targeted area. This research was a descriptive study that design the primers using Geneious software version 5.4.7. The study was conducted at the Laboratory of Genetics and Biotechnology FMIPA Universitas Negeri Padang. Based on this research, a 10qF forward primer (NG_012631.1) and 10qR reverse primers (NG_012631.1) has successfully designed. The primers can amplify the targeted area of the TCF7L2 gene with $1208 \mathrm{bp}$ length. The amplified gene region has many variants that are strictly related to the appearance of Type 2 Diabetes Mellitus.
\end{abstract}

Copyright $@ 2020$ Universitas Islam Negeri Raden Fatah Palembang. All Right Reserved

\section{Introduction}

Diabetes Mellitus (DM) is a disease characterized by high blood sugar levels because of the lack of insulin hormone in the body. Deficiency can be in the form of insufficient amounts of insulin, or the body cannot effectively use insulin (Kariadi \& Sri Hartini KS, 2009). Uncontrolled blood sugar levels can increase the risk of complications and can cause death (Fahmiyah \& Latra, 2016).

Data from the International Diabetes Federation (IDF) shows that in 2019 there were around 351.7 million adults (aged 2064 years) in the world suffering from Diabetes Mellitus. The number is expected to increase until it reaches 417.3 million by 2030 and to 486.1 million by 2045 . The World Health Organization (2016) suggests that there are 3.7 million deaths due to diabetes and high glucose levels. An increase in DM cases also occurred in Indonesia, IDF state that the prevalence of $\mathrm{DM}$ in Indonesia is $6.2 \%$ and rank $7^{\text {th }}$ in the world. RISKESDAS primary health research data (2013) shows that the prevalence of DM in Indonesia reaches 1.5 percent of the total population (Departemen Kesehatan Republik Indonesia, 2013; Diabetes Federation International, 2019; World Health Organization, 2016).

Diabetes Mellitus can classify into three general types, include; Type-1 Diabetes Mellitus, Gestational Diabetes, and Type-2 Diabetes Mellitus (American Diabetes Association, 2017). The damage of pancreatic beta cells by a virus or autoimmunity causes Type-1 Diabetes 
Mellitus. Gestational diabetes occurs in women who are pregnant (Soelistijo et al., 2015), whereas Type-2 Diabetes Mellitus is a metabolic disorder characterized by an increase in blood sugar due to decreased insulin secretion by pancreatic beta $(\beta)$ cells (insulin resistance) and impaired insulin function (Soelistijo et al., 2015).

The prevalence of Type-2 Diabetes Mellitus is higher than the other type of DM. The prevalence of T2DM reaches 90$95 \%$ of all people with diabetes. Generally, T2DM patients aged over 45 years, but lately, the sufferers among children and adolescents also increase in the population (Tama, F.S., \& Hermansyah, 2011).

Type-2 Diabetes Mellitus is a multifactorial disease, which is determined by the environmental and genetic factor (Erkoç Kaya, Arikoğlu, Kayiş, Öztürk, \& Gönen, 2017). Genetically, T2DM is caused by polymorphisms in genes associated with the incidence of T2DM disease.

Several gene variants have shown an association with T2DM in some populations. These gene variants include polymorphisms in the calpain 10 (CAPN10), peroxisome proliferatoractivated receptor $\gamma$ (PPARG), ATPsensitive inwardly rectifying potassium channel subunit Kir6.2 (KCNJ11), hepatocyte nuclear factor 4 (HNF4A), hepatic transcription factor 1 (TCF1), and transcription factor 7-like 2 (TCF7L2) gene (Sale et al., 2007). The TCF7L2 gene reported having a strong association with T2DM in Danish, Caucasian, Indian, and the other ethnic groups in Asia (Radha \& Mohan, 2007).

The TCF7L2 gene, formerly known as TCF-4, is part of the transcription factor with high mobility. The location of this gene is on chromosome $10 \mathrm{q}$ of the human genome. The TCF7L2 gene is a major transcription factor for the $\mathrm{WNT} / \beta$-catenin signaling pathway, which has an essential role in beta-cell survival and regeneration (Yao et al., 2015). Jin et al. (2008) also suggested that the TCF7L2 gene plays a role in the WNT signaling process during embryonic development and in regulating gene expression in adulthood. WNT signaling disorders become one of the causes of insulin resistance (Yao et al., 2015)(Jin \& Liu, 2008).

Many studies explain the association of the TCF $7 L 2$ gene as one of the causes of the T2DM disease. As revealed by the research of Votsi et al. (2017), T2DM is associated with five Single Nucleotide Polymorphism (SNP) statistically in the Greek population. rs7901695 TCF7L2 gene is one of the examples of the associated SNP (Votsi et al., 2017).

Based on several study, it can conclude that the standard technique used to detect $T C F 7 L 2$ gene polymorphisms is Fragment Length Polymorphism (RFLP) (Elrod \& Stansfield, 2007). The weakness of this technique is that the number of polymorphism sites that can be observed is limited to one point because, in principle, the RFLP method is only able to recognize polymorphisms on changes in restriction sites due to polymorphisms.

Another method that can detect polymorphisms in the TCF7L2 gene is sequencing. The main objective of this method is to evaluate the sequence of nucleotides in a genome with very high accuracy, including the presence of polymorphisms in that sequence(Franca, Carrilho, \& Kist, 2002). TCF7L2 gene fragments are needed as a template to sequence the TCF7L2 gene. A method to amplify the DNA fragment from the genome is the Polymerase Chain Reaction (PCR) technique.

Polymerase Chain Reaction is an enzymatic method for multiplying specific nucleotide sequences in vitro. The advantage of the PCR method is that this reaction can be carried out using minimal amounts of components. This method also has a high level of specificity in amplifying a fragment. Many factors determine the uniqueness of the fragment be amplified; one of the main factors is the specificity of the primer (Yuwono, 2006). 
The primer is a sequence of short oligonucleotides (15-25 nucleotides bases) that initiate DNA chain synthesis in the polymerase chain reaction. The success of a PCR process is mostly determined by the sequence of the primers (Yuwono, 2006). Several things must be considered in designing a primer for PCR, include: the GC content of each primer must be in the range of $40-60 \%$. Then, it is necessary to know whether the primers do not overlap with other primers in the reaction mixture, because this will encourage the formation of a dimer primer. Software used to optimization the construction of the primer (Borah, 2011).

As stated earlier, some polymorphisms are known to be strongly associated with T2DM (Votsi et al., 2017). Some of these variants are in a nearly close position. Based on bioinformatics studies, regions with such variants have $\pm 1208 \mathrm{bp}$ length. The sequencing method can detect the polymorphism in the TCF7L2 gene, but there are still no specific primers that can be used on these methods.

Based on the description above, an appropriate pair of primers are needed to amplify the TCF7L2 gene that will be used in the sequencing method. Therefore, research will be carried out on the primer construction to amplify the TCF $7 L 2$ gene.

\section{Materials and Methods}

This study was done from February to April 2018 at the Laboratory of Genetics and Biotechnology, Biology Department, Faculty of Mathematics and Natural Sciences, Padang State University. This research is a descriptive study that describes the results of primer construction and confirms the primer ability to amplify the desired area.

\section{Tools and Materials}

The tools used in this study were: thermocycler (Biorad), LC Carousel Centrifuge 2.0 (Roche), micropipette (Eppendorf, Biorad), tube (Eppendorf), microtube, vortex (Thermolyne), chamber, microtube rack, power supply, tip, PCR tube, and camera, digital dry bath (Labnet), autoclave (Hirayama).

The materials used in this study include DNA Mold, primer, Go Taq Green Master mix (Promega, USA), Buffer (Promega, USA), $\mathrm{MgCl}_{2}$ (Biorad), $\mathrm{H}_{2} \mathrm{O}$, agarose (Vivantis), Nuclease Free water, and EDTA.

\section{Research Preparation}

All tools and materials for this study were sterilized by autoclave at $121{ }^{\circ} \mathrm{C}$ and 15 psi (per square inch) for 15 minutes.

\section{TCF7L2 gene Analysis}

TCF7L2 gene analysis was performed using bioinformatics software. The TCF $7 L 2$ gene sequence was obtained from the NCBI bank gene on the website www.ncbi.nlm.gov and PubMed.

\section{Primer Construction}

The primer was constructed using Geneious software version 5.4.7 (Biomatters Ltd). The primers were designed to amplify regions in the TCF7L2 gene that have more than one adjacent SNP. The Ability of Primer to Amplify the Area

\section{The isolation of DNA}

The TCF7L2 gene was isolated from brachial venous blood using a $3 \mathrm{ml}$ syringe and stored in micro collection tube gel. DNA Purification Kit (Invitrogen) was used to separate the DNA.

Polymerase Chain Reaction (PCR) for TCF $7 L 2$ gene Amplification

The TCF7L2 gene was amplified from human DNA by the Polymerase Chain Reaction. A pair of primers was used to expand the desired area. The formula used in this study were Go Taq Green Master mix (Promega), primers, nuclease-free water, and DNA Mold. The PCR condition used in this study was the initial denaturation at $94^{\circ} \mathrm{C}$ for 3 minutes. Followed by denaturation phase at $94^{\circ} \mathrm{C}$ for 30 seconds, annealing at the temperature melting of primer for 30 seconds, and elongation phase at $72^{\circ} \mathrm{C}$ for one minute for a total of 45 cycles. The reaction was closed 
with final elongation at $72^{\circ} \mathrm{C}$ for 5 minutes. The PCR process will be optimized until maximum results were obtained.

Agarose

Agarose (Vivantis) (1\%) was made by add 0.5 grams of agarose powder and 50 $\mathrm{mL}$ TAE $1 \mathrm{X}$ in a $100 \mathrm{~mL}$ Erlenmeyer. The mixture then dissolved in a water-bath while stirring until the color becomes transparent. After the temperature of agarose reached $60^{\circ} \mathrm{C}$, add $1 \mu \mathrm{L}$ of $\mathrm{EtBr}$ (ethidium bromide), and poured the mixture into a mold.

\section{Electrophoresis}

The agarose was placed in an electrophoresis bath and added TAE $1 \mathrm{X}$ until the whole agar was soak. Add 1,3 $\mu \mathrm{L}$ of HindIII Ladder DNA (Promega) into the first well, and the mixture of $5 \mu \mathrm{L}$ PCR product and $1 \mu \mathrm{L}$ loading dye (methylene blue, xylene xyanole, sucrose) into the other well. After that, closed the electrophoresis bath and connected it to an electric current. Electrophoresis was carried out for 30 minutes with a voltage of $100 \mathrm{~V}$. The electrophoresis results then checked by UV illuminator.

\section{Data Analysis}

Data in the form of analysis of the results of primer construction by Bioinformatics and the primer ability to amplify the TCF7L2 gene were analyzed descriptively.

\section{Result and Discuss \\ TCF $7 L 2$ gene analysis}

This study aimed to construct a primer to detect the TCF7L2 gene. Based on bioinformatics analysis on SNP position from menu OMIM and SNP www.ncbi.nlm.gov, there were three adjacent SNP in the TCF7L2 gene. The results of SNP mapping on the TCF7L2 gene can be seen in Figure 1.

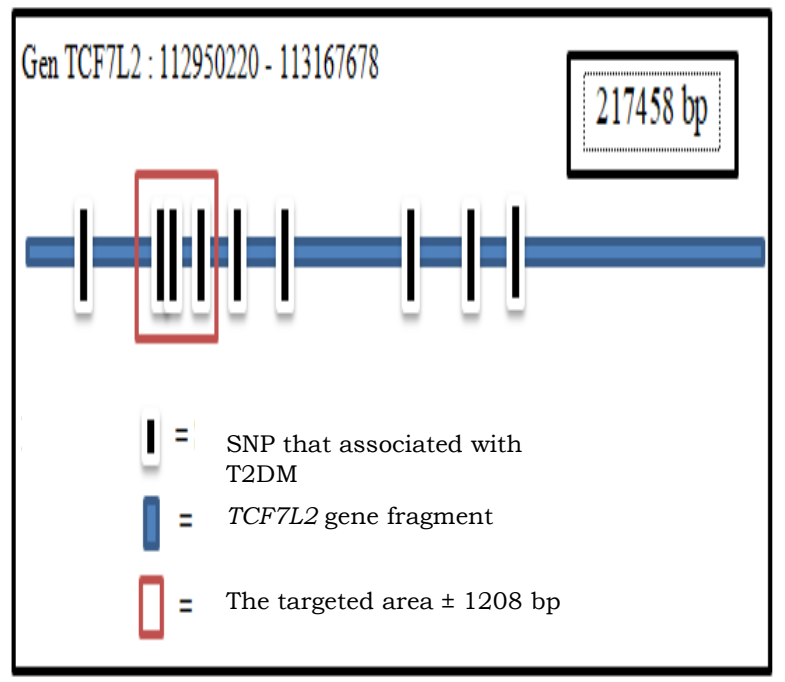

Figure 1. SNP mapping in the TCF7L2 gene.

In Figure 1, there were 3 adjacent SNP (Polymorphism) include: SNP rs34872471, SNP rs7901695, and SNP rs35198068 on TCF7L2 gene. SNP rs34872471, rs7901695, and rs35198068 reported to have a strong association with T2DM in Saudi Arabia, Danish, Iceland, America, and Malaysia. (Ghassibe-Sabbagh et al., 2014)(Cook \& Morris, 2016) (Abuhendi et al., 2019)(Grant et al., 2006) (Huzaimi, 2009). The three SNP's also expected to be associated in Indonesia so it can be used as T2DM marker.

\section{Primer Construction}

In this study, the construction of the primer was done by the Geneious software version 5.4.7 (Biomatters Ltd). The constructed primers were forward primer $(10 \mathrm{qF})$ and reversed primer $(10 \mathrm{qR})$. Both of these primers are used to amplify the TCF7L2 gene, which covers an area of \pm $1208 \mathrm{bp}$. The amplified area has 3 SNPs that are strongly associated with T2DM disease. Construction results can be seen in Table 1.

Table 1. Primer Construction Result of $10 \mathrm{qF}$ and $10 \mathrm{qR}$ primer.

\begin{tabular}{|c|c|c|c|}
\hline \multirow{5}{*}{ Primer 10qF } & \multicolumn{3}{|c|}{ Sequence: $\quad$ 5'-CCATTAGCAGTCACTCCTCA-3' } \\
\hline & \multicolumn{2}{|r|}{ Criteria } & Result \\
\hline & $\% \mathrm{GC}$ & Min 50, Max 60 & 50 \\
\hline & $\mathrm{Tm} \mathrm{C}$ & Min 55, Max 80 & 66 \\
\hline & No Hairpin & Energy cutoff $0.0 \mathrm{kcal}$ & -- \\
\hline
\end{tabular}




\begin{tabular}{|c|c|c|c|}
\hline & & & \\
\hline & No 3' Dimers & Reject $>=3$ matches at 3 end & 1 \\
\hline & No Dimers & Reject $>=7$ adj homol bases & 3 \\
\hline & No Runs & Reject $>=3$ base runs & 2 \\
\hline & No 3'GC runs & Reject $>=3 \mathrm{G}$ or $\mathrm{C}$ at $3^{\prime}$ end & 0 \\
\hline \multirow{9}{*}{ Primer $10 \mathrm{qR}$} & \multicolumn{3}{|c|}{$\begin{array}{ll}\text { Sequence: } & \text { 5'-AGAGAGCAGGTGGTCACTCC-3' } \\
& \text { (Complementary Strand) }\end{array}$} \\
\hline & \multicolumn{2}{|r|}{ Criteria } & Result \\
\hline & $\% \mathrm{GC}$ & Min 50, Max 60 & 60 \\
\hline & $\mathrm{Tm} \mathrm{C}$ & $\operatorname{Min} 55, \operatorname{Max} 80$ & 69 \\
\hline & No Hairpin & Energy cutoff $0.0 \mathrm{kcal}$ & -- \\
\hline & No 3' Dimers & Reject $>=3$ matches at $3^{\prime}$ end & 2 \\
\hline & No Dimers & Reject $>=7$ adj homol bases & 3 \\
\hline & No Runs & Reject $>=3$ base runs & 2 \\
\hline & No 3'GC runs & Reject $>=3 \mathrm{G}$ or $\mathrm{C}$ at $3^{\prime}$ end & 2 \\
\hline
\end{tabular}

The construction of the primer is one of the essential factors in the success of a PCR reaction. According to Syamsurizal (2013), the primer is responsible for recognizing and marking DNA template segments that will be amplified. In the PCR reaction, the primers will limit the target DNA fragments that will be amplified and, at the same time, provide a hydroxy group $(-\mathrm{OH})$ at the 3 'end that is needed for the process of DNA existence (Syamsurizal, Yanwirasti, Manaf, \& Jamsari, 2014; Yusuf, 2010).

In Table 1, it can be seen that the two primers have a close melting temperature ( can use as annealing temperature), i.e., $66^{\circ} \mathrm{C}$ and $69^{\circ} \mathrm{C}$ (forward and reverse respectively). Both primers also have fewer dimers than the other primers that can be the basis for choosing these two primers. It was also expressed by Diffenbach and Dveksler (1995) that several things that must be considered in constructing the primer are: The length of the primer, the last nucleotide in the primer, the ratio of GC, Tm (Melting Temperature), and the presence of dimers (Syamsurizal, Handayani, Kadri, \& Badriyya, 2019); (Yusuf, 2010).

\section{Confirmation of Primer Design}

The designed primer $10 \mathrm{qF}$ and $10 \mathrm{qR}$ then analyze to determine the possibility of primer mismatch with other regions in the human genome. The mismatch is an attachment error during the Annealing process in the PCR reaction (Syamsurizal \&
Kadri, 2018; Yuwono, 2006). The results of the analysis can be seen in Figure 2.

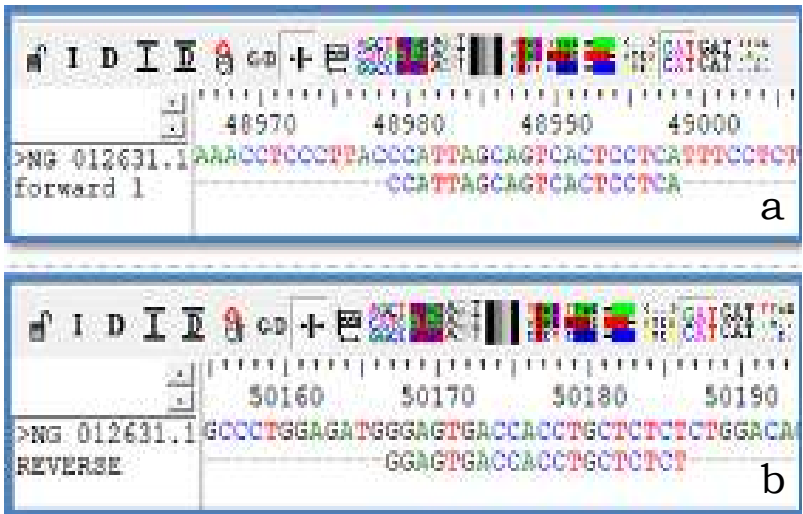

Figure 2. The result of the constructed primer alignment to $T C F 7 L 2$ gene; a: $10 q F$ forward primer alignment with the genome, b: reversed primer $10 q R$ alignment.

Based on the alignment results in Figure 2, it can be concluded that the primer attached to the correct position. The position of forwarding primer was at 48,979 bp, while the reverse primer at 50,186 bp. This result is consistent with the primer construction results in Table 1.

\section{Confirmation of Primer Design using PCR Reaction}

The constructed primers then confirmed using a PCR reaction. The determination of the annealing temperature was based on the primer melting temperature. In this study, the PCR reaction was carried out using a gradient PCR method with annealing temperature 
variations of $56.5^{\circ} \mathrm{C}, 58.5{ }^{0} \mathrm{C}$, and $60.5{ }^{0} \mathrm{C}$ (gradient \pm 4.5 ). The result of the PCR reaction were analyzed using the electrophoresis method at $0.5 \%$ agarose. The results of the visualization can be seen in Figure 3.

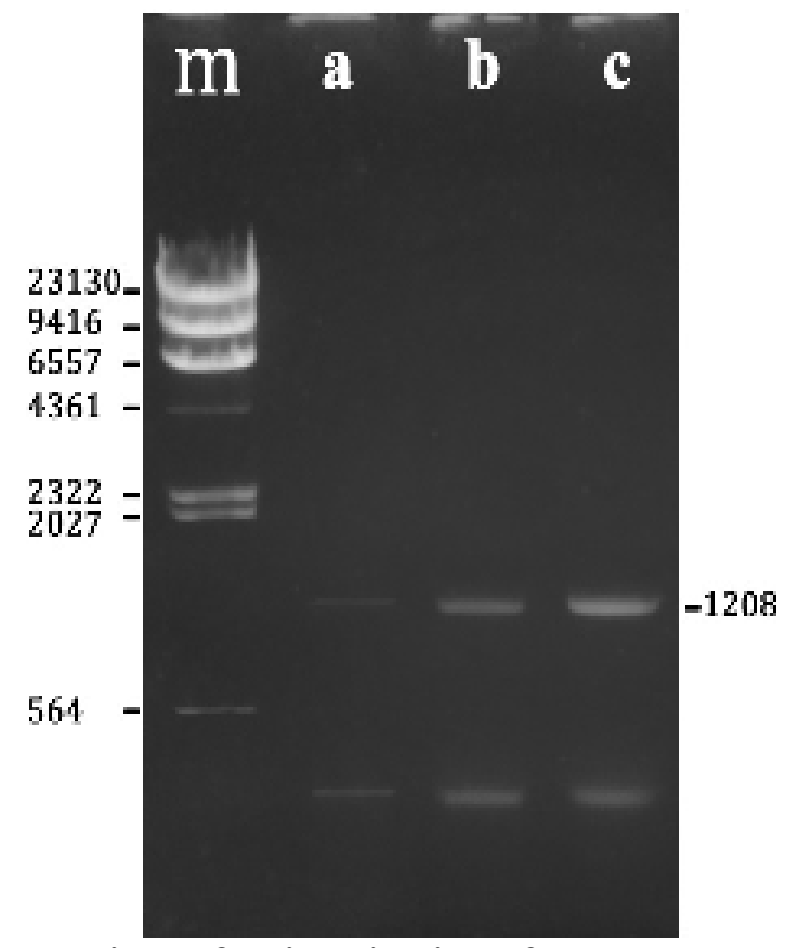

Figure 3. Visualization of sample electrophoresis. m: marker. a: the PCR product with annealing temperature at

$56,5{ }^{\circ} \mathrm{C}$. b: the $\mathrm{PCR}$ product with annealing temperature at $58,5^{\circ} \mathrm{C}$. c: the PCR product with annealing temperature at $60,5{ }^{\circ} \mathrm{C}$.

In Figure 3, there was a band in the position between $500 \mathrm{bp}$ and $2027 \mathrm{bp}$, that follow the prediction that the primer would amplify the DNA fragments along with \pm 1208 bp. Besides, these results were not optimal because there was still an unspecific band at a position below the 500 bp. Nevertheless, it can be concluded that the primers constructed have succeeded in amplifying the TCF7L2 gene fragment, which is closely related to the risk of type 2 Diabetes Mellitus.

From the PCR product obtained from this study, it can be concluded that PCR products with an annealing temperature of $60.5{ }^{\circ} \mathrm{C}$ (c) were give a better result than the other two PCR products. This result can be seen in Figure 3, where the PCR tape looks thicker, more precise, and the unspecific band formed is even less. Therefore, the PCR reaction can be used to amplify the targeted area of the TCF7L2 gene with \pm 1208 bp length. The PCR reaction can be used to amplify an area that consist of three SNP, so that in one reaction we can identify 3 types of SNPs at once.

\section{Conclusion}

Based on this research, it can be concluded that:

1. A pair of primers have been successfully constructed, namely forward primer $10 \mathrm{qF}$ (NG_012631.1) and reverse primer 10qR (NG_012631.1).

2. The constructed primers were able to amplify the targeted area of the TCF $7 L 2$ gene along $\pm 1208 \mathrm{bp}$, wherein the range has many polymorphism sites that found to be strongly associated with the risk of Type 2 Diabetes Mellitus.

\section{References}

Abuhendi, N., Qush, A., Naji, F., Abunada, H., Al Buainain, R., Shi, Z., \& Zayed, H. (2019). Genetic polymorphisms associated with type 2 diabetes in the Arab world: A systematic review and meta-analysis. Diabetes Research and Clinical Practice, 151, 198-208. https://doi.org/10.1016/j.diabres.2019.0 3.037

American Diabetes Association. (2017). Standards of Medical Care in Diabetes2017.

Borah, P. (2011). Primer designing for PCR. Science Vision, 11(3), 134-136.

Cook, J. P., \& Morris, A. P. (2016). Multiethnic genome-wide association study identifies novel locus for type 2 diabetes susceptibility. European Journal of Human Genetics, 24(8), 1175-1180.

https://doi.org/10.1038/ejhg.2016.17

Departemen Kesehatan Republik Indonesia. (2013). Laporan Riset Kesehatan Dasar (Riskesdas), Bagian Penyakit 
Tidak Menular. jakarta: Badan Litbangkes, Depkes RI.

Diabetes Federation International. (2019).

IDF Diabetes Atlas 2019. In

International Diabetes Federation.

Retrieved

from

http://www.idf.org/about-

diabetes/facts-figures

Elrod, S. L., \& Stansfield, W. D. (2007). Genetika (4th editio). jakarta: erlangga.

Erkoç Kaya, D., Arikoğlu, H., Kayiş, S. A., Öztürk, O., \& Gönen, M. S. (2017). Transcription factor 7-like 2 (TCF7L2) gene polymorphisms are strong predictors of type 2 diabetes among nonobese diabetics in the Turkish population. Turkish Journal of Medical Sciences, $\quad 47(1), \quad 22-28$. https://doi.org/10.3906/sag-1507-160

Fahmiyah, I., \& Latra, N. I. (2016). Faktor yang Mempengaruhi Kadar Gula Darah Puasa Pasien Diabetes Mellitus Tipe 2 di Poli Diabetes RSUD Dr. Soetomo Surabaya Menggunakan Regresi Probit Biner. Jurnal Sains Dan Seni ITS, 5(2), 2337-3520.

Franca, L. T. C., Carrilho, E., \& Kist, T. B. L. (2002). A review of DNA sequencing techniques. Quarterly Review of Biophysics, 35(2), 169-200.

Ghassibe-Sabbagh, M., Haber, M., Salloum, A. K., Al-Sarraj, Y., Akle, Y., Hirbli, K., ... Zalloua, P. A. (2014). T2DM GWAS in the Lebanese population confirms the role of TCF7L2 and CDKAL1 in disease susceptibility. Scientific Reports, 4, 7351. https://doi.org/10.1038/srep07351

Grant, S. F. A., Thorleifsson, G., Reynisdottir, I., Benediktsson, R., Manolescu, A., Sainz, J., ... Stefansson, K. (2006). Variant of transcription factor 7-like 2 (TCF7L2) gene confers risk of type 2 diabetes. Nature Genetics, 38(3), 320-323. https://doi.org/10.1038/ng1732

Huzaimi, M. (2009). Association of TCF7L2 variants with type 2 diabetes mellitus susceptibility and treatment outcome in a multi-ethnic malaysian population.
University of Malaya, Kuala Lumpur.

Jin, T., \& Liu, L. (2008). The Wnt signaling pathway effector TCF7L2 and type 2 diabetes mellitus. Molecular Endocrinology, 22(11), 2383-2392. https://doi.org/10.1210/me.2008-0135

Kariadi, \& Sri Hartini KS. (2009). Diabetes? Siapa Takut!! Panduan Lengkap Untuk Diabetisi, Keluarganya, dan Profesional Medis. Bandung: PT. Mizan Pustaka.

Radha, V., \& Mohan, V. (2007). Genetic predisposition to type 2 diabetes among Asian Indians. The Indian Journal of Medical Research, 125(3), 259-274.

Sale, M., Smith, S. G., Mychaleckyj, J. C., Keene, K. L., Langefeld, C. D., Leak, T. S., ... Freedman, B. I. (2007). Gene Are Associated With Type 2 Diabetes in an African-American Population Enriched for Nephropathy. October, 56(October), 2638-2642. https://doi.org/10.2337/db070012.Additional

Soelistijo, S., Novida, H., Rudijanto, A., Soewondo, P., Suastika, K., Manaf, A., ... Soetedjo, N. (2015). Konsesus Pengelolaan Dan Pencegahan Diabetes Melitus Tipe2 Di Indonesia 2015. In Perkeni. Retrieved from https://www.google.com/url?sa=t\&sour ce=web\&rct=j\&url=https://pbperkeni.o r.id/wp-content/uploads/2019/01/4.-

Konsensus-Pengelolaan-dan-

Pencegahan-Diabetes-melitus-tipe-2-diIndonesia-PERKENI-

2015.pdf\&ved=2ahUKEwjy8KOs8cfo AhXCb30KHQb1Ck0QFjADegQIBhA $\mathrm{B} \&$ usg $=\mathrm{AOv}$

Syamsurizal, \& Kadri, H. (2018). Genotyping SNP Rs12255372 TCF7L2 Gene Using Three-Primer ARMS-PCR for Detection T2DM $\mathrm{n}$ Indonesian Batak Ethnic. Journal of Physics: Conference Series, 1040(1). https://doi.org/10.1088/17426596/1040/1/012003

Syamsurizal, S., Handayani, D., Kadri, H., \& Badriyya, E. (2019). Genotyping SNP rs7903146 TCF7L2 gene for 
detection T2DM in Indonesian melayu ethnic Genotyping SNP rs7903146 TCF7L2 gene for detection T2DM in Indonesian melayu ethnic. Journal of Physics: Conference Series, 1317, 1-8. https://doi.org/10.1088/17426596/1317/1/012090

Syamsurizal, S., Yanwirasti, Manaf, A., \& Jamsari. (2014). Konstruksi Primer untuk Deteksi SNP rs12255372 pada Gen Transcription Factor 7 Like 2 (TCF7L2) Penyebab Diabetes Melitus Tipe-2 dengan Metode Amplification Refractory Mutation System (ARMS)PCR. Prosiding Seminar Nasional Dan Wordshop Perkembangan Terkini Sains Farmasi Klinik 3. Padang.

Tama, B. A., F.S., R., \& Hermansyah. (2011). An early detection method of type-2 diabetes mellitus in public hospital. TELKOMNIKA, 9(2), 287294.

Votsi, C., Toufexis, C., Michailidou, K., Antoniades, A., Skordis, N., Karaolis, M., ... Christodoulou, K. (2017). Type 2 Diabetes Susceptibility in the GreekCypriot Population: Replication of Associations with TCF7L2, FTO, HHEX, SLC30A8 and IGF2BP2 Polymorphisms. Genes, 8(1). https://doi.org/10.3390/genes8010016

World Health Organization. (2016). Global Report on Diabetes. France.

Yao, D. D., Yang, L., Wang, Y., Liu, C., Wei, Y. J., Jia, X. B., ... Shu, L. (2015). Geniposide promotes beta-cell regeneration and survival through regulating $\beta$-catenin/TCF7L2 pathway. Cell Death and Disease, 6(5), e174613. https://doi.org/10.1038/cddis.2015.107

Yusuf, Z. K. (2010). Polymerase Chain Reaction (PCR). Saintek, 5(6), 1-6.

Yuwono, T. (2006). Teori dan Aplikasi Polymerase Chain Reaktion. Yogyakarta: andi. 